\title{
Obsidian economy on the Cauria Plateau (South Corsica, Middle Neolithic): New evidence from Renaghju and I Stantari
}

\author{
Marie Orange a, b, *, F.-X. Le Bourdonnec a , André D'Anna ${ }^{c}$, Pascal Tramoni ${ }^{\mathrm{d}}$, Carlo Lugliè ${ }^{\mathrm{e}}$, \\ Ludovic Bellot-Gurlet $^{\mathrm{f}}$, Anja Scheffers ${ }^{\mathrm{b}}$, Henri Marchesi ${ }^{\mathrm{g}}$, J.L. Guendon ${ }^{\mathrm{c}}$, \\ Renaud Joannes-Boyau ${ }^{\mathrm{b}}$
}

\author{
a IRAMAT-CRP2A, UMR 5060 CNRS-Université Bordeaux Montaigne, Maison de l'Archéologie, Esplanade des Antilles, 33607, Pessac Cedex, France \\ b Southern Cross GeoScience, Southern Cross University, Military Road, PO Box 157, Lismore, NSW 2480, Australia \\ c Aix-Marseille Université, Laboratoire Méditerranéen de Préhistoire Europe-Afrique (LAMPEA), UMR 7269 CNRS, MMSH, BP 647, 5 rue du Château de \\ l'Horloge, 13094, Aix-en-Provence, Cedex 2, France \\ d INRAP Méditerranée, UMR 5140, Archéologie des Sociétés Méditerranéennes, 390 avenue de Pérols, 34970, Lattes, France \\ e LASP, Dipartimento di Storia, Beni Culturali e Territorio, Università di Cagliari, 09124, Cagliari, Italy \\ f Sorbonne Universités, UPMC Université Paris 6, MONARIS 'de la Molécule aux Nano-objets: Réactivité, Interactions et Spectroscopies', UMR 8233, \\ UPMC-CNRS, 75005, Paris, France \\ ${ }^{g}$ DRAC/SRA de Languedoc-Roussillon, Hôtel de Grave, 5 rue Salle-l'Évêque, 34000, Montpellier, France
}

\section{A R T I C L E I N F O}

\section{Article history:}

Received 10 May 2017

Received in revised form

9 December 2017

Accepted 17 December 2017

\section{Keywords:}

Obsidian sourcing

LA-ICP-MS

Corsica

Cauria plateau

Middle Neolithic

\begin{abstract}
A B S T R A C T
This paper aims to study and compare the obsidian economies of Renaghju and I Stantari, two neighbouring Neolithic sites located on the Cauria plateau (south-western Corsica). The occupation phase 3 of Renaghju and phase 1 of I Stantari, both attributed to the Middle Neolithic (fifth millennium BC), have provided respectively 112 and 99 obsidian artefacts. With the aim of completing our rather lacunary knowledge of the obsidian consumption behaviours in place in Corsica during this period, the entire assemblages have been geochemically characterised virtually non-destructively using LA-ICP-MS at SOLARIS (Southern Cross University [SCU]). Our analyses revealed that, while the obsidian raw materials were exclusively sourced from the Monte Arci complex in Sardinia (SA, SB2, and SC sub-types only), rather different consumption patterns are observed for the two sites despite their comparable nature (megalithic sites) and geographical proximity (400 m apart). These differences in obsidian consumption on adjacent sites could be explained by their divergent functions (ceremonial site [Renaghju] vs. ceremonial locus and large settlement [I Stantari]), or eventually point towards the need for a readjustment of the chronological attribution of the I Stantari phase 1 occupation level.
\end{abstract}

() 2017 Elsevier Ltd and INQUA. All rights reserved.

\section{Introduction}

Obsidian sourcing has long been a successful tool for the study of past population movements, by retracing cultural contacts and

\footnotetext{
* Corresponding author. IRAMAT-CRP2A, UMR 5060 CNRS-Université Bordeaux Montaigne, Maison de l'Archéologie, Esplanade des Antilles, 33607, Pessac Cedex, France.

E-mail addresses: marie.orange@u-bordeaux-montaigne.fr, marie.orange@scu. edu.au (M. Orange), Francois-Xavier.Le-Bourdonnec@u-bordeaux-montaigne.fr (F.-X. Le Bourdonnec), danna@mmsh.univ-aix.fr (A.D'Anna), pascal.tramoni@ inrap.fr (P. Tramoni), luglie@unica.it (C. Lugliè), ludovic.bellot-gurlet@upmc.fr (L. Bellot-Gurlet), anja.scheffers@scu.edu.au (A. Scheffers), henri.marchesi@ culture.gouv.fr (H. Marchesi), guendon@mmsh.univ-aix.fr (J.L. Guendon), renaud. joannes-boyau@scu.edu.au (R. Joannes-Boyau).
}

revealing procurement, trade, and exchange patterns (e.g., Cann and Renfrew, 1964; Williams-Thorpe, 1995; Poupeau et al., 2010a). Often treated as an end itself instead of as a 'means to an end', the discipline has deeply evolved in the recent decades to embrace a more integrated and contextualised approach. Lately, the following trends can be observed:

- the development of analytical strategies (Carter et al., 2006; Le Bourdonnec, 2007; Orange et al., 2017), relying on the combination of different techniques (virtually or strictly nondestructive) to achieve the exhaustive characterisation of the assemblages. As already illustrated in various studies (e.g., Lugliè et al., 2009; Orange et al., 2013; Freund, 2014), such an approach allows the extraction of the maximum amount of 
information from the lithic assemblages and is crucial to better understand the economy of the obsidian material at site level and in a larger regional context;

- the integration of the sourcing results with the typotechnological information (e.g., Carter et al., 2006; Eerkens et al., 2008) in order to better apprehend the use of the raw material and discuss in detail the chaîne opératoire. This sometimes reveals complex consumption patterns - where 'diffusion' does not always equate to 'interaction' between two groups (Perlès, 2012). Among the areas where those research perspectives are being followed, the Western Mediterranean is undoubtedly one of the most prosperous. By the means of collaborative and multidisciplinary research projects, more than 11, 000 artefacts (all periods combined) have hitherto been sourced in this region (Poupeau et al., 2014). It is also where, through a close collaboration between archaeologists and archaeometrists, the typo-technological aspects have regularly been integrated to the chemical analyses in the study of complete collections (Lugliè et al., 2007, 2008, 2009; Bressy et al., 2010; Poupeau et al., 2010b; Le Bourdonnec et al., 2010, 2011, 2012, 2015; Freund and Tykot, 2011 inter alia).

Aiming to follow these trends, the present paper opens the discussion on the obsidian economy of the Middle Neolithic occupation levels of the Renaghju (phase 3) and I Stantari (phase 1) settlements. We focus here on achieving the sourcing of both assemblages, and on comparing the results obtained with the adjacent chronological periods and the surrounding area. In order to associate the typo-technological data with the sourcing information (which is, as mentioned above, a crucial aspect for the reconstruction of raw material economies), a synchronic and diachronic discussion on the sourcing and technological data incorporating the study of several lithic assemblages from the Cauria plateau is currently in preparation, and will complement this first paper.

The strength of the present study lies in the investigation of complete assemblages originating from thoroughly dated and/or contextualised stratigraphic levels, clearly connected to the general cultural evolution of the Neolithic in Corsica and attributed to well-defined cultural groups. It will thus significantly contribute to a better perception and definition of the Middle Neolithic in Corsica, and of the groups that are a part of it.

Situated on the Cauria plateau, one of the most informative areas for the study of the Neolithic period in Corsica (D'Anna et al., 2007a, 2007b; D'Anna, 2011), the Renaghju and I Stantari settlements are chiefly renowned for their stone alignments (Fig. 1), spotted by Prosper Mérimée as early as 1839 (Mérimée, 1840). Both sites present relatively long, substantial, and complex settlement sequences (D'Anna et al., 2001, 2007a, 2007b; D'Anna, 2014), and

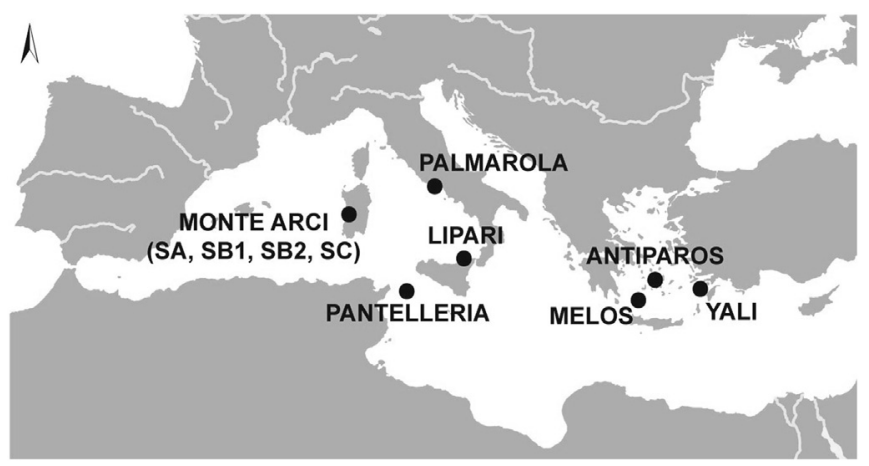

Fig. 2. General map of the Mediterranean area displaying the main obsidian sources of the Western Mediterranean (Monte Arci [SA, SB1, SB2, SC], Lipari, Palmarola, Pantelleria) and the Aegean (Melos, Yali, Antiparos).

therefore are rich in information about the social, cultural, and economic patterns in place at the time. Yet only the Cardial Early Neolithic level of Renaghju (phase 1) has so far been thoroughly studied and published (Bressy et al., 2003, 2007; Le Bourdonnec et al., 2015).

The latest publication (Le Bourdonnec et al., 2015), involving a total of 622 obsidian artefacts sourced either by visual characterisation, Particle-induced X-ray emission spectroscopy [PIXE], or Scanning Electron Microscopy with Energy Dispersive Spectroscopy [SEM-EDS], has shown that the majority of the Renaghju (phase 1) assemblage was made using obsidian originating from the Monte Arci area in Sardinia (see Fig. 2), mainly from the SA sub-source (45.3\%), followed by the SB2 (35.4\%) and SC (19.1\%) sub-sources. One artefact was found to match the distant source of Palmarola (eastern Tyrrhenian Sea; Fig. 2), thus indicating rather early (sixth millennium $\mathrm{BC}$ ) direct or indirect contact(s) between the two islands. This illustrates the multiple links and groups displacements between the islands of the Western Mediterranean, through the complex Neolithisation processes and evolutions. In this paper, the obsidian consumption patterns in place during the Middle Neolithic levels at Renaghju and I Stantari are studied and compared to each other (synchronic perspective), and then put in contrast with the results previously obtained on the Early Neolithic occupation level (phase 1) of Renaghju (diachronic perspective; see Le Bourdonnec et al., 2015 for the complete study of the EN obsidian assemblage of Renaghju).

\section{Archaeological background}

An important amount of material originated from Renaghju and I Stantari (D'Anna et al., 2006, 2007a, 2007b; D'Anna, 2011, 2014),

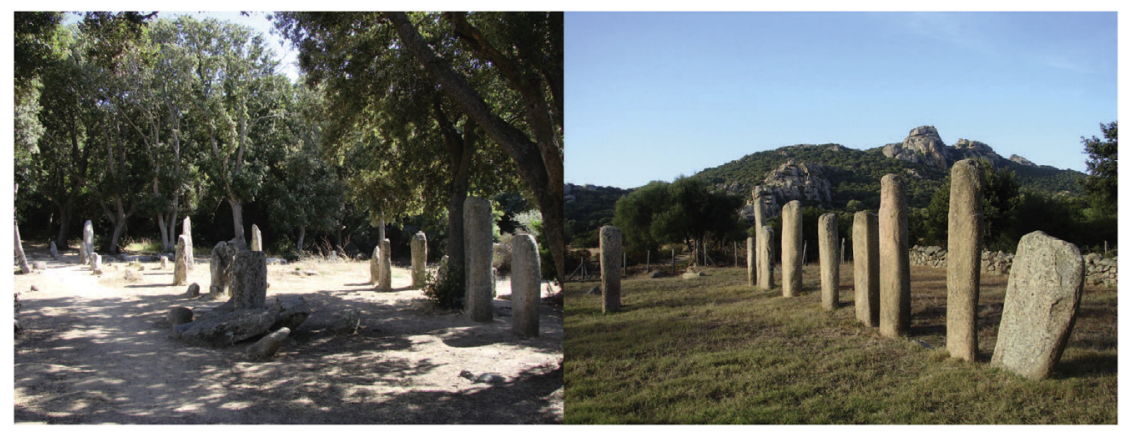

Fig. 1. Stone alignments of the Renaghju (left) and I Stantari (right) sites. 
especially in terms of the lithic industries. Until now, research had solely focused on the origin of chert and obsidian artefacts present in the Early Neolithic Cardial level of Renaghju (Bressy et al., 2003, 2007; Le Bourdonnec et al., 2015). The I Stantari site, just like the Neolithic and Bronze Age levels of Renaghju, had only been the focus of limited investigations within the official excavation report.

\subsection{Renaghju}

More than 20 years after the last surveys on the Renaghju site (1975), a new series of programmed excavations were finally conducted, taking place between 1994 and 2000. They allowed the excavation of a large area (ca. $\left.500 \mathrm{~m}^{2}\right)$, thus producing a substantial amount of documentation (D'Anna et al., 2002, 2003, 2006; D'Anna, 2014).

The present paper includes the study of the obsidian lithic assemblage associated with the phase 3 occupation level megalithic structure. Two small structures made of heated rocks were found within this level and have been the object of radiocarbon dating, placing them between 4685 and 4365 cal BC ( $2 \sigma$; LY-10229: $5685 \pm 55 \mathrm{BP})$, with probability peaks at 4515,4499 , and $4465 \mathrm{cal}$ BC (D'Anna et al., 2007a; D'Anna, 2014). The phase 3 megalithic monument is thus assigned to the Middle Neolithic period, which we consider to take place at ca. $4600-4400$ cal BC. Through the study of the obsidian artefacts, we therefore aim to provide a first insight into the Middle Neolithic period on the Cauria plateau.

In addition to the 112 obsidian artefacts excavated in the phase 3 level (see examples in Fig. 3), we also note the presence of items made of quartz, hyaline quartz, rhyolite, chert, and other hard rocks. If we exclude the quartz of local origin and for which the actual use for the production of tools and weapons can be questioned, the main raw material is obsidian (41\% of the assemblage, vs. $31 \%$ for the chert and $26 \%$ for the rhyolite). These proportions differ greatly from what has been observed for the same materials in the phase 1 occupation level (65\% chert, $21 \%$ obsidian, $13 \%$ rhyolite).

\subsection{Stantari}

At the northern boundary of the Pozzu Rossu and approximately $400 \mathrm{~m}$ north of the Renaghju settlement, I Stantari is located at the upper end of the Cauria plateau (cf. Fig. 4).

The base of the stratigraphy integrates the first architectural structures, made of small stelae situated near a large built-up area. This constitutes the phase 1 of the I Stantari settlement. The monument's organisation is difficult to determine, comprising a minimum of 30 sub-trapezoidal and rectangular stelae without any particular orientation. The excavated artefacts (ceramics and lithic industry) and the comparisons made with the Renaghju site places the use of this monument to the Middle Neolithic period, and thus contemporary with Renaghju phase 3 .

The lithic industry of this Middle Neolithic level has only been the object of unpublished preliminary studies. It comprises a total of 200 artefacts made of obsidian (see examples in Fig. 3), chert, rhyolite, and quartz, which have not all necessarily been knapped. Obsidian is slightly dominant, representing $50 \%$ of the total assemblage - or $56 \%$ if quartz is excluded. The proportion of chert represents $28 \%$ (32\% if quartz is excluded), and rhyolite $10 \%$ ( $11 \%$ if quartz is excluded). The artefacts are of small dimensions (between 3 and $20 \mathrm{~mm}$ ), with numerous broken fragments. The obsidian industry is mainly represented by small flakes, but also by bladelets. The tools made from flakes or bladelets exhibit either irregular lateral removals or continuous abrupt retouch for the realisation of geometric tools. The pièces esquillées dominate the assemblage.

Two important observations can therefore be made about this assemblage: (a) the obsidian raw material is predominantly used, and (b) most of the assemblage (ca. 80\%) is made of rocks originating from Sardinia, while raw materials available either in Corsica or more locally on the Cauria plateau (e.g., rhyolite) are of secondary importance. Furthermore, primary flakes, secondary flakes, and nucleus fragments suggest that knapping was performed in situ.

\section{Obsidian sourcing}

\subsection{Analytical protocols}

The Laser Ablation Inductively Coupled Plasma Mass Spectrometry [LA-ICP-MS] analytical method has demonstrated its efficiency for obsidian sourcing (see, for example, Gratuze, 1999; Carter et al., 2006; Barca et al., 2007; Orange et al., 2016). Virtually non-destructive, this technique is fast enough (a few minutes per sample) to allow the geochemical characterisation of large collections within a reasonable time frame. Furthermore, the specific set of trace elements assayed allows the discrimination of obsidian sources from various geographical contexts.

In this study, the samples were analysed at the SOLARIS laboratory (Southern Cross GeoScience, Southern Cross University) following a LA-ICP-MS protocol recently optimized for obsidian sourcing in the Mediterranean (Orange et al., 2016). Because the analyses were conducted by micro-sampling - laser ablation - on the surface of the artefacts, the sample preparation only involved the cleaning of the objects. After being placed $5 \mathrm{~min}$ in an ultrasonic bath to remove potential contamination from soil, they were rinsed successively with tap water, distilled water, ethanol, and acetone, then dried in the open air. The analytical instrument itself consists of an Agilent 7700 Series ICP-MS, coupled to a NWR213 laser ablation system (Nd:YAG deep UV laser at $213 \mathrm{~nm}$ ). The MassHunter Workstation software is used to control the instrument, acquire and analyse the data. The ablation parameters applied to the artefacts are reported in Table 1; this protocol was developed to reduce the ablation of the archaeological objects to a minimum - i.e., approximately the width of a human hair $(40 \mu \mathrm{m})$. A total of 14 isotopes, which allow the discrimination of Mediterranean obsidian sources, were measured: ${ }^{45} \mathrm{Sc},{ }^{66} \mathrm{Zn},{ }^{85} \mathrm{Rb},{ }^{88} \mathrm{Sr}$, ${ }^{89} \mathrm{Y}$, ${ }^{90} \mathrm{Zr},{ }^{93} \mathrm{Nb},{ }^{133} \mathrm{Cs},{ }^{137} \mathrm{Ba},{ }^{146} \mathrm{Nd},{ }^{147} \mathrm{Sm},{ }^{208} \mathrm{~Pb},{ }^{232} \mathrm{Th}$, and ${ }^{238} \mathrm{U}$. At the beginning and end of each run, the international standard NIST SRM 613 was analysed to ensure the accuracy (always better than $6.5 \%$, see Table 2), precision and reproducibility of our measurements (see Orange et al., 2016). Statistical treatment of the geochemical data and graphical representations were carried out using the JMP software (10.0.2, SAS Inc.)

\subsection{Sampling}

Thanks to the swiftness of the analytical protocol, the geochemical compositions of the entire obsidian assemblages from the Middle Neolithic level of both sites (211 artefacts in total) were determined. No selection of the artefacts was performed beyond a first sorting with the naked eye by raw material type. However, if quartz and chert are easy to visually distinguish from obsidian, small artefacts made of rhyolite can sometimes be more difficult to differentiate from the less glassy types of Sardinian obsidian. In such cases, the artefact was selected for geochemical analysis to try to determine its classification.

The performed analyses thus involved 112 artefacts for Renaghju phase 3, and 99 for I Stantari phase 1. Their chemical signatures were compared to those of the main obsidian sources of the Mediterranean (cf. Fig. 2). This reference database consists of 200 geological samples from our collection (see Orange et al., 2016, 2017), originating from sources located in Sardinia (Monte Arci 
SA

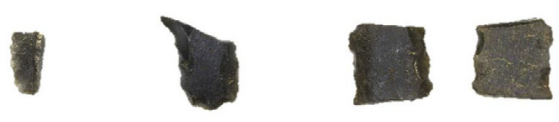

$\begin{array}{lll}\text { SCU.ARCH.125 SCU.ARCH.141 SCU.ARCH.138 } & \text { S }\end{array}$
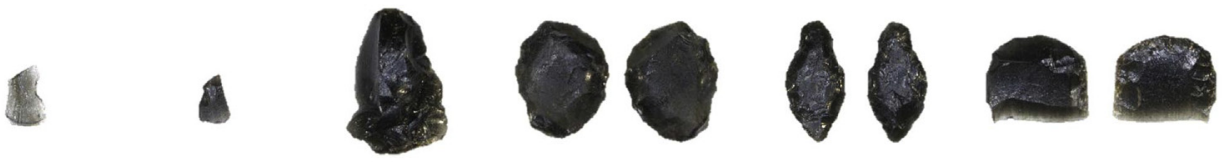

SCU.ARCH.24

SCU.ARCH.104

SCU.ARCH. 38

SCU.ARCH.49

SCU.ARCH.22

SCU.ARCH.21
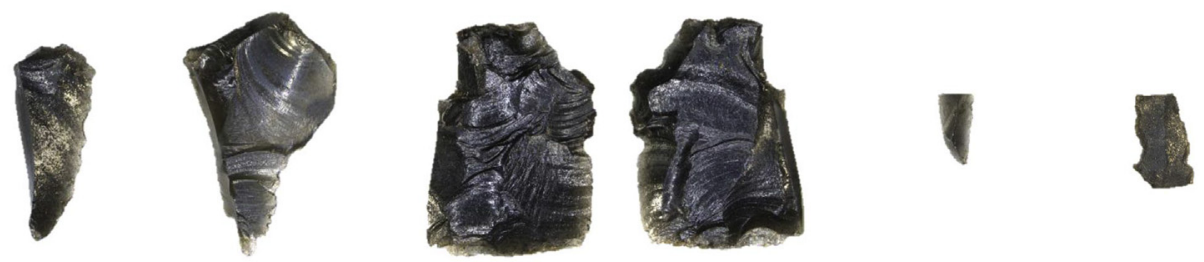

SCU.ARCH.35

SCU.ARCH. 81

SCU.ARCH.20

SCU.ARCH.124

SCU.ARCH.164
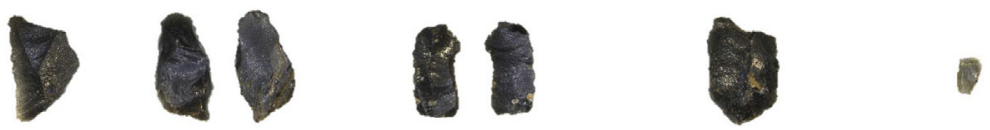

SCU.ARCH.139

SCU.ARCH.143

SCU.ARCH. 170

SCU.ARCH.190

SCU.ARCH.204

$\underline{\text { SC }}$
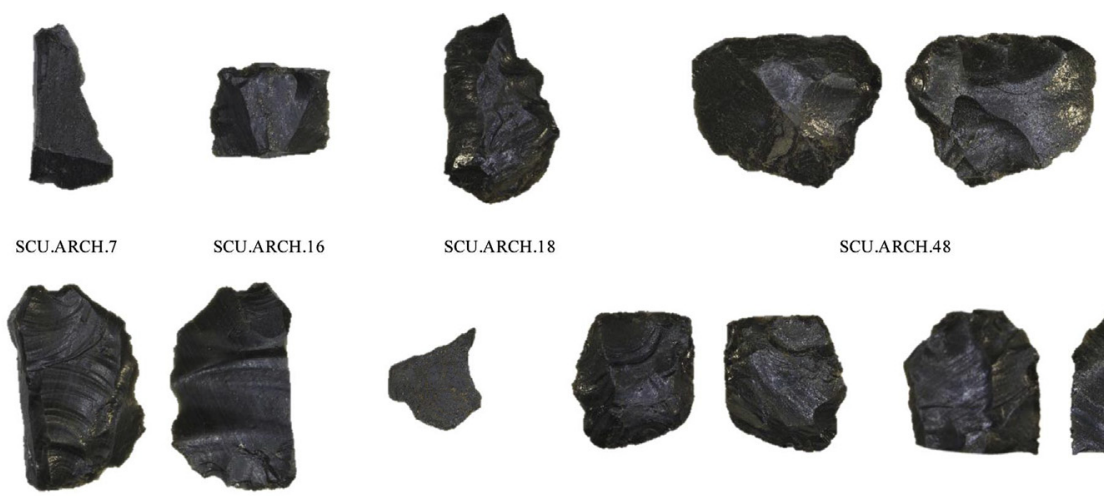

SCU.ARCH. 18

SCU.ARCH.48

SCU.ARCH.51

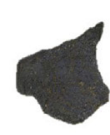

SCU.ARCH.52

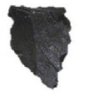

SCU.ARCH.193
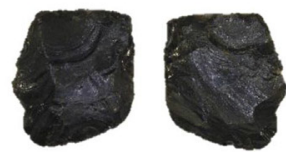

SCU.ARCH.54

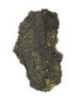

SCU.ARCH.207

SCU.ARCH.208

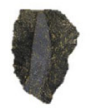

SCU.ARCH.209

Ind.

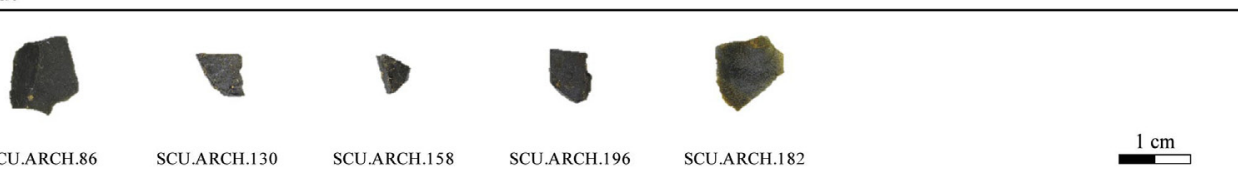

SCU.ARCH.86

Fig. 3. Examples of obsidian artefacts from the Renaghju phase 3 and I Stantari assemblages. 


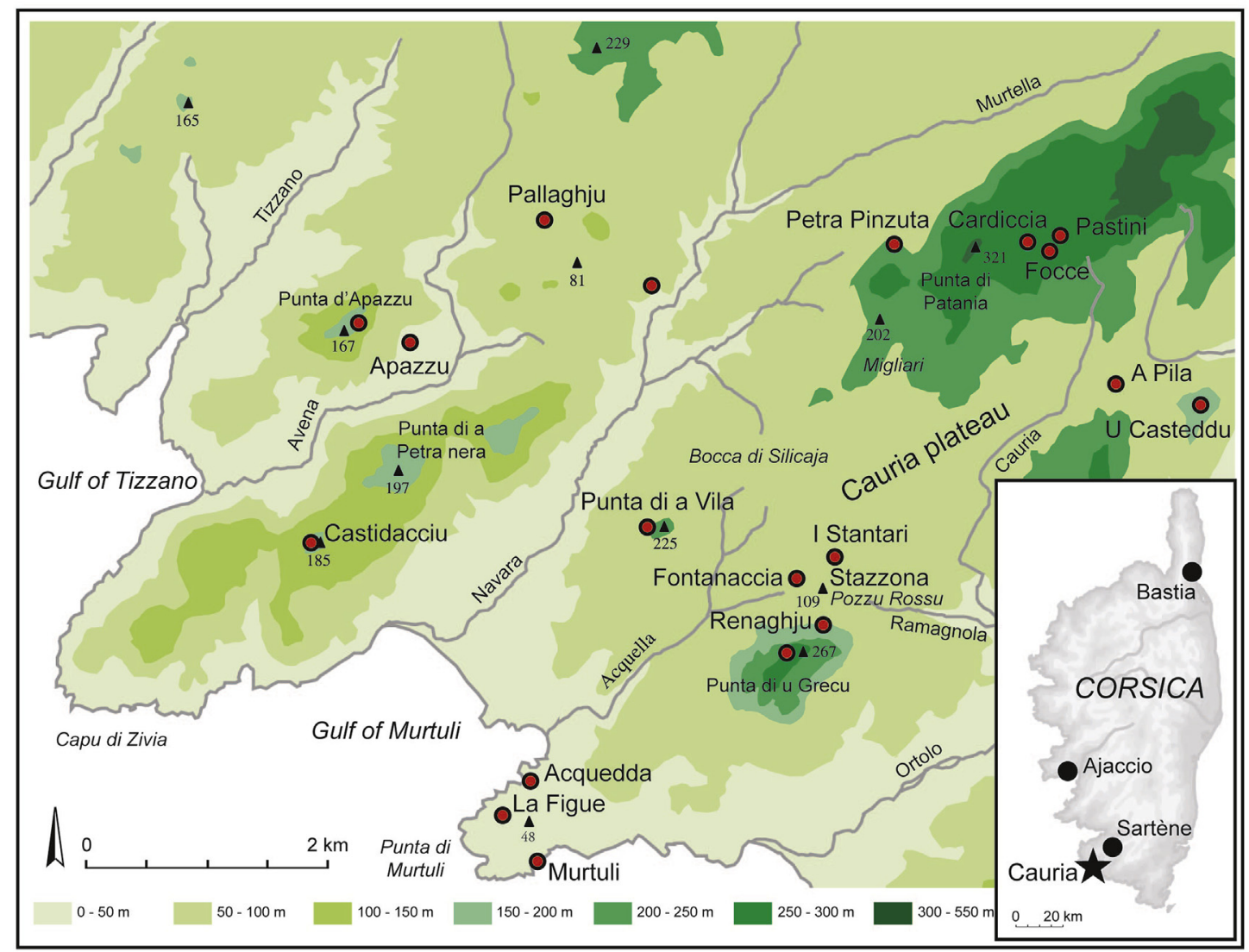

Fig. 4. Location of the Cauria plateau and the main archaeological sites cited in the text.

Table 1

Ablation parameters adopted for the LA-ICP-MS analyses conducted on the archaeological samples at SOLARIS (SCU, Australia). The ablation parameters used for the geological samples can be found in Orange et al. (2016), along with the analytical protocol developed.

\begin{tabular}{ll}
\hline Ablation parameters & Archaeological samples \\
\hline Spot size & $40 \mu \mathrm{m}$ \\
Laser pulse frequency & $10 \mathrm{~Hz}$ \\
Laser power (output) & $80 \%$ \\
Scan speed & $5 \mu \mathrm{m} / \mathrm{s}$ \\
Depth & $10 \mu \mathrm{m}$ \\
Passes & 1 \\
Line length & $0.6 \mathrm{~mm}$ \\
Total time acquisition per line & $2: 15 \mathrm{~min}$ \\
\hline
\end{tabular}

complex: SA, SB1, SB2, and SC sub-types), Lipari, Palmarola, Pantelleria (Balata dei Turchi and Lago di Venere), the Carpathian basin, and the Aegean Sea (Melos, Yali, and Antiparos).

\subsection{Sourcing results}

\subsubsection{Renaghju}

The complete obsidian assemblage of Renaghju phase 3 (112 artefacts), has been geochemically characterised by LA-ICP-MS (see Supplementary data 1$)$. Given that the compositions « [...] provide information on relative rather than absolute values of the components of compositions, that relative values are characterised by ratios and that logarithms of ratios are simpler to handle mathematically and interpret statistically than ratios » (Aitchison et al., 2002:3) motivated our choice to use a logratio (i.e., logarithms of the ratios of the concentrations) analysis (see also Aitchison, 1982) instead of
Table 2

Comparison of the ${ }^{45} \mathrm{Sc},{ }^{66} \mathrm{Zn},{ }^{85} \mathrm{Rb},{ }^{88} \mathrm{Sr},{ }^{89} \mathrm{Y},{ }^{90} \mathrm{Zr},{ }^{93} \mathrm{Nb},{ }^{133} \mathrm{Cs},{ }^{137} \mathrm{Ba},{ }^{146} \mathrm{Nd},{ }^{147} \mathrm{Sm}$, ${ }^{208} \mathrm{~Pb},{ }^{232} \mathrm{Th}$, and ${ }^{238} \mathrm{U}$ contents with uncertainty ( \pm 1 standard deviation) obtained on the NIST SRM 613 standard during this study (16 measurements over 8 runs) and the reference values recommended by the NIST and the GeoRem database. Relative error calculated in comparison with the GeoRem reference values. Concentrations are in ppm.

\begin{tabular}{|c|c|c|c|c|}
\hline & \multirow{2}{*}{$\frac{\text { NIST }}{\text { Concentration }}$} & \multirow{2}{*}{$\frac{\text { GeoRem }}{\text { Concentration }}$} & \multicolumn{2}{|c|}{ This study (16 measures) } \\
\hline & & & Concentration (1sd) & Relative error \\
\hline${ }^{45} \mathrm{Sc}$ & & $39.9(2.5)$ & $38.5(0.8)$ & $3.6 \%$ \\
\hline${ }^{66} \mathrm{Zn}$ & & $39.1(1.7)$ & $41.0(4.2)$ & $4.9 \%$ \\
\hline${ }^{85} \mathrm{Rb}$ & $31.4(0.4)$ & $31.4(0.4)$ & $30.5(0.5)$ & $2.9 \%$ \\
\hline${ }^{88} \mathrm{Sr}$ & $78.4(0.2)$ & $78.4(0.2)$ & $76.2(1.1)$ & $2.8 \%$ \\
\hline${ }^{89} \mathrm{Y}$ & & $38.3(1.4)$ & $37.0(0.5)$ & $3.5 \%$ \\
\hline${ }^{90} \mathrm{Zr}$ & & $37.9(1.2)$ & $36.9(0.4)$ & $2.7 \%$ \\
\hline${ }^{93} \mathrm{Nb}$ & & $38.9(2.1)$ & $37.3(0.4)$ & $4.2 \%$ \\
\hline${ }^{133} \mathrm{Cs}$ & & $42.7(1.8)$ & $40.0(0.6)$ & $6.4 \%$ \\
\hline${ }^{137} \mathrm{Ba}$ & $38.6(2.6)$ & $39.3(0.9)$ & $38.7(0.8)$ & $1.6 \%$ \\
\hline${ }^{146} \mathrm{Nd}$ & 36 & $35.5(0.7)$ & $33.6(0.6)$ & $5.3 \%$ \\
\hline${ }^{147} \mathrm{Sm}$ & 39 & $37.7(0.8)$ & $36.2(0.6)$ & $4.1 \%$ \\
\hline${ }^{208} \mathrm{~Pb}$ & $38.57(0.2)$ & $38.57(0.2)$ & $38.89(1.95)$ & $0.82 \%$ \\
\hline${ }^{232} \mathrm{Th}$ & $37.79(0.08)$ & $37.79(0.08)$ & $35.69(0.58)$ & $5.55 \%$ \\
\hline${ }^{238} \mathrm{U}$ & $37.38(0.08)$ & $37.38(0.08)$ & $35.98(0.54)$ & $3.79 \%$ \\
\hline
\end{tabular}

a standard multivariate analysis for the statistical treatment of the data obtained. The $\mathrm{Zr}$, Nb, and $\mathrm{Cs}$ being amongst the most significant elements for the characterisation of obsidians, they are frequently used for sources discrimination as well as artefact attribution in the Western Mediterranean (Tykot et al., 2011; Terradas et al., 2014; Freund, 2014 i.a.) and elsewhere (Orange et al., 2013; Kellett et al., 2013, i.a.). Therefore, we chose to compare the $\log \left({ }^{133} \mathrm{Cs} /{ }^{93} \mathrm{Nb}\right)$ and $\log \left({ }^{90} \mathrm{Zr} /{ }^{93} \mathrm{Nb}\right)$ ratios (Fig. 5) 


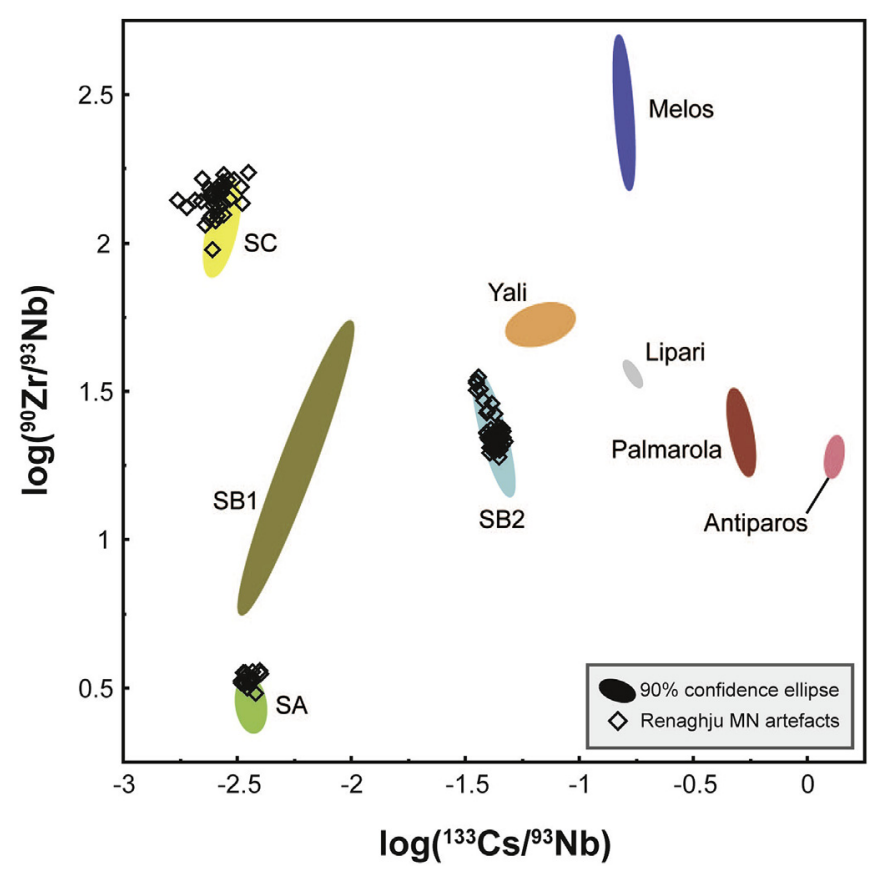

Fig. 5. Comparison of the $\log \left({ }^{133} \mathrm{Cs} /{ }^{93} \mathrm{Nb}\right)$ and $\log \left({ }^{90} \mathrm{Zr} /{ }^{93} \mathrm{Nb}\right)$ ratios obtained by LA-ICPMS on 111 artefacts from the Renaghju phase $3(\mathrm{MN})$ assemblage and 200 geological samples from the Mediterranean area (Monte Arci [SA, SB1, SB2, SC], Lipari, Palmarola, Melos, Yali, and Antiparos; see Orange et al., 2016 for the complete data on the geological samples). 90\% normal density ellipses. For reasons of clarity, the sources of Pantelleria (Balata dei Turchi and Lago di Venere) and the Carpathians are not represented in the graph.

Table 3

Number of artefacts - and proportions within the complete assemblage - attributed to each source for the Renaghju and I Stantari Middle Neolithic assemblages.

\begin{tabular}{llllll}
\hline SITE & Nb. artefacts & SA & SB2 & SC & Other facies \\
\hline Renaghju Phase 3 & \multirow{2}{*}{112} & 16 & 58 & 37 & 1 unknown \\
\% of the assemblage & & $14 \%$ & $52 \%$ & $33 \%$ & $>1 \%$ \\
I Stantari Phase 1 & 99 & 6 & 38 & 51 & 4 unknowns \\
\% of the assemblage & & $6 \%$ & $38 \%$ & $52 \%$ & $4 \%$ \\
\hline
\end{tabular}

which clearly discriminate all the Mediterranean sources and illustrate that 58 artefacts can be attributed to the SB2 sub-source, 37 to SC, and 16 to SA (see Table 3). Besides $\mathrm{Zr}$, Nb, and Cs, Sr was also found to be a diagnostic element, and clearly confirms the attributions made using the logratio analysis: for the artefacts assigned to the SC group, its contents vary from 87 to $143 \mathrm{ppm}$, while it is much lower for SA and SB2, ranging between 20-25 ppm and $22-45 \mathrm{ppm}$ respectively. The $\mathrm{Y}, \mathrm{Ba}$, and Th values were also used to match the artefacts to the sources. Only one artefact (SCU.ARCH.86, see Fig. 3 and Supplementary data 1), run several times to ensure the results, could not be matched to any source of our geological database. A further macroscopic examination, showing a fine-grained matrix, suggests that this object could be made of rhyolite rather than obsidian.

\subsubsection{Stantari}

A total of 99 obsidian objects excavated from the phase 1 (Middle Neolithic) occupation level of I Stantari were analysed by LA-ICP-MS (see Supplementary data 2). The same logratio analysis as for the Renaghju assemblage, comparing the $\log \left({ }^{133} \mathrm{Cs} /{ }^{93} \mathrm{Nb}\right)$ and $\log \left({ }^{90} \mathrm{Zr} /{ }^{93} \mathrm{Nb}\right.$ ) ratios (Fig. 6), allowed us to identify the presence of the same obsidian raw materials (SA, SB2, and SC), although in different proportions. Four artefacts remain unassigned and could

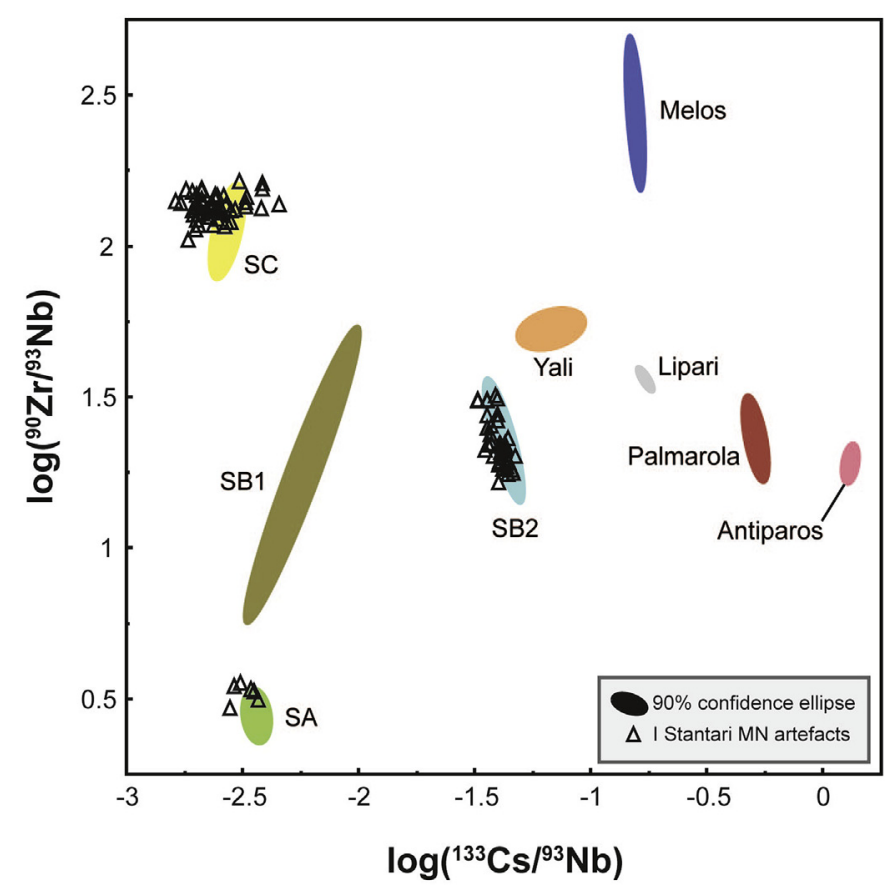

Fig. 6. Comparison of the $\log \left({ }^{133} \mathrm{Cs} /{ }^{93} \mathrm{Nb}\right)$ and $\log \left({ }^{90} \mathrm{Zr} /{ }^{93} \mathrm{Nb}\right)$ ratios obtained by LA-ICPMS on 95 artefacts from the I Stantari phase 1 (MN) assemblage and 200 geological samples from the Mediterranean area (Monte Arci [SA, SB1, SB2, SC], Lipari, Palmarola, Melos, Yali, and Antiparos; see Orange et al., 2016 for the complete data on the geological samples). $90 \%$ normal density ellipses. For reasons of clarity, the sources of Pantelleria (Balata dei Turchi and Lago di Venere) and the Carpathians are not represented in the graph.

possibly represent a different source or material type (see below). It was revealed that the majority of the items was made of SC obsidian (51 artefacts, about half of the assemblage), 38 artefacts were attributed to SB2, and 6 to SA. The $\mathrm{Zr}$ values, very close to those obtained for Renaghju (66-76 ppm for the artefacts made of SA obsidian; $82-112 \mathrm{ppm}$ for SB2; $185-233 \mathrm{ppm}$ for SC) clearly show the three clusters corresponding to each source. Nonetheless, a total of 4 artefacts remain of an unknown origin (SCU.ARCH.130, SCU.ARCH.158, SCU.ARCH.182, and SCU.ARCH.196; see Fig. 3 and Supplementary data 2), as their chemical composition could not clearly match our sources. The SCU.ARCH.182 sample, comparably to SCU.ARCH.86 in the Renaghju assemblage, has revealed a finegrained matrix suggesting a rhyolite. The remaining unknowns are presenting similar visual characteristics: dark grey, sometimes slightly blue semi-opaque to opaque glass with a greasy lustre. While several elements ( $\mathrm{Rb}, \mathrm{Cs}, \mathrm{Nd}$, Th) could suggest a SB2 origin, strontium contents $(74,83$, and $92 \mathrm{ppm})$ are closer to those of the SC source (75-123 ppm, see Orange et al., 2016), and too high to match the SB2 group (20-52 ppm). Likewise, zirconium contents (150,170, and $188 \mathrm{ppm}$ ) appear to be too high to correspond to the SB2 group (ranging from 82 to $124 \mathrm{ppm}$ ), whereas it seems to match the SC group better (174-233 ppm). The presence of these distinctive materials, already observed on other sites in Corsica and Sardinia (unpublished results) and possibly corresponding to rhyolites or to some intermediary facies between rhyolite and obsidian, will be investigated in the future to allow their interpretation as well as to complete the exhaustive study of the whole lithic assemblages considered.

\section{Discussion}

Within Corsica, it has always been apparent that the obsidian raw materials mostly came from Sardinia (Courtin, 1972; 
Lanfranchi, 1976, 1980, 1987; Vaquer, 2007), as confirmed by the most recent studies (e.g., Bressy et al., 2007, 2008; Le Bourdonnec et al., 2010, 2015). With the exception of Basi (south-western Corsica; see Tykot, 1996, 2002) and Renaghju phase 1 (Le Bourdonnec et al., 2015), previous studies have generally been conducted on a limited number of samples, scarcely representative of the whole assemblages, sometimes collected from poorly dated and intermingled occupation levels, and whose real significance can be quite unclear. Such uncertainties constitute a serious obstacle to the formulation of detailed and grounded interpretations on the obsidian circulation patterns (Costa and Cesari, 2003; Costa, 2006). The present study, on the contrary, was conducted on the complete assemblages from Renaghju phase 3 and I Stantari phase 1, whose occupation levels have been clearly defined.

The importance of obsidian in lithic material supply to Corsica clearly increased from the Early Neolithic (EN) to the Middle Neolithic (MN): marginal during the EN phases, this raw material becomes more frequent in the $\mathrm{MN}$ levels where it sometimes dominates over other rocks, as is the case at Vasculacciu or Tivulaghju. It is only in the Recent Neolithic Basian sites that obsidian became highly dominant (75\% at Basi and Monte Grosso, and $88 \%$ at Costa di u Monte, among other sites). In both Renaghju and I Stantari Middle Neolithic (MN) levels, obsidian is the main raw material used for the lithic industries, and it largely dominates over chert (and quartz). However, subsequent studies will be needed to confirm this trend in the larger context of the Cauria plateau and the Sartene region.

For both sites, the results obtained by LA-ICP-MS analysis clearly show an exclusive use of the Sardinian sources of the Monte Arci area - SA, SB2, and SC (cf. Table 3). The SB1 sub-type is completely absent from both assemblages, which matches the general tendency for the whole Neolithic period in Corsica and Sardinia (Lugliè et al., 2008), and can probably be explained by the lower knapping qualities of its obsidian.

In Renaghju phase 3, the predominance of the SB2 sub-type which constitutes about $52 \%$ of the entire obsidian assemblage - is unusual, but not unheard of: its preferential use is a common behaviour in the sources' contact zone and outside Sardinia during both the EN and the first stages of MN (e.g., Lugliè et al., 2007, 2008). However, the relatively high frequency of SC sub-type obsidians (33\%) is more surprising, in particular when compared to the amount of SA sub-type obsidians (14\%). Such 'deficiency' in SA sub-type obsidians as compared to the SC sub-type is a relatively new feature, even amongst the evolutions observed during the second half of the fifth millennium BC. Nonetheless, a similar case seems to appear (although only 50 artefacts were analysed by X-ray Fluorescence spectroscopy [XRF]) at Costa di U Monte (PoggioMezzana commune, Haute-Corse) where only $24 \%$ of the artefacts are matched with SA while $76 \%$ matched with SC (Bressy et al., 2008). When a significant number of artefacts is analysed, the SA and SC obsidian sub-types are usually consumed in relatively equal proportions. For example, this is the case for the obsidian assemblage of the MN level of Basi (Sicurani, 2008) where, over 125 objects characterised with an Electron Microprobe coupled to a Wavelength Dispersive Spectrometer [EMP-WDS], 45\% matched the SA sub-type and 50\% matched the SC sub-type. However, at Basi and Costa di U Monte the SB2 sub-type is mostly absent (completely absent in the latter, and only $3 \%$ of the assemblage in the former).

Similarly, the obsidian distribution of I Stantari phase 1 does not correlate with the general picture of obsidian diffusion outside of Sardinia during the MN period, with a relatively high use of the SB2 sub-type obsidian (38\% of the assemblage). Here, the SC sub-type is predominant (52\%), followed by a sporadic use of the SA sub-type
(6\%). In the few sites available for comparison, SA and SC usually prevail (slightly more SC than SA), as observed in Basi (MN; Sicurani, 2008), I Calanchi (LN; Sicurani, 2008; Le Bourdonnec et al., 2010), and Costa di U Monte (Poggio-Mezzana, MN/LN; Bressy et al., 2008).

Unfortunately, few obsidian-bearing Middle Neolithic Corsican sites are available for comparison, and even fewer have had their obsidian assemblage exhaustively characterised. In the current state of knowledge, however, we can observe that during the Middle Neolithic period the SC obsidian sub-type is generally dominant at Corsican sites. It is the case in the $\mathrm{G}$ sector at the Vasculacciu site (Bressy et al., 2008), whereas in the B sector the SB2 and SC sub-types are equally prevalent. The preponderance of SC has also been observed at Costa di U Monte, A Fuata, and Monte Revincu, as well as at the Recent Neolithic sites of Basi and Monte Grosso.

If we compare the obsidian consumption in Renaghju between the EN and the MN periods (Fig. 7), a clear shift in the proportions of each Sardinian obsidian sub-type can be observed: the use of the SA obsidian sub-type, slightly prevailing over SB2 during the EN with $45 \%$ of the assemblage, is considerably reduced during the MN (14\%). The SB2 obsidians are the most widely used (52\%), followed by SC (33\%). This change could potentially be explained by the relatively limited number of artefacts present in the phase 3 assemblage. The 'anomalous' ratio might hence have been emphasized by the presence of just a few raw matter units/blanks introduced and reduced at the site accordingly to different strategies/methods. A thoroughly combined visual/technological analysis is needed to be able to offer further insights.

The situation is different again at I Stantari (see Fig. 7), where the proportions are inverted - SC is dominant (52\%), followed by SB2 (38\%) and SA (6\%). The difference between the MN levels of Renaghju and I Stantari will have to be confirmed. If substantiated, it could potentially be explained in two different ways. A first hypothesis relies on the function of the sites: while Renaghju is solely a ceremonial site, I Stantari combines both a ceremonial locus and a large settlement. A second hypothesis involves their chronology: the available data suggest that the two sites are not exactly contemporaneous. The material and radiometric dating show that Renaghju belongs to the early phase of the Middle Neolithic (Corsican facies Bonu Ighinu; 4800-4400 BC), while I Stantari, like Monte Revincu (Leandri et al., 2007; Bressy et al., 2008), could be associated with the end of the fifth millennium BC (Presian style,

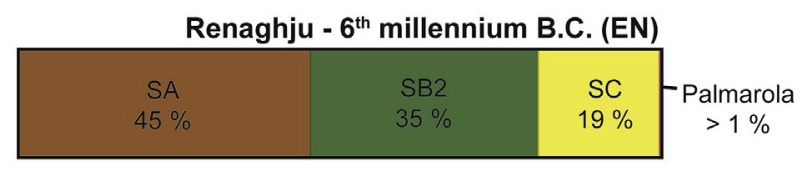

Renaghju $\mathbf{5}^{\text {th }}$ millennium B.C. (MN)

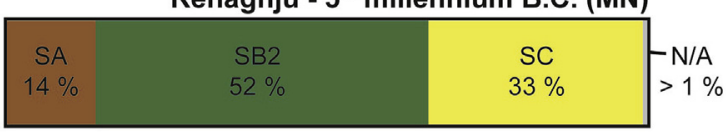

I Stantari - $5^{\text {th }}$ millennium B.C. (MN)

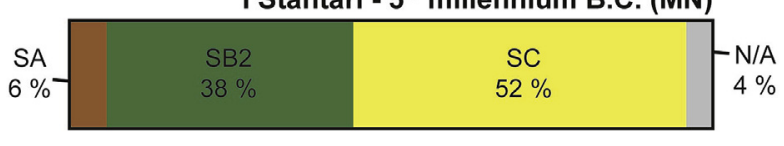

Fig. 7. Bar charts ( $100 \%$ stacked columns) comparing the obsidian consumption revealed at Renaghju phase $1(\mathrm{EN})$, Renaghju phase $3(\mathrm{MN})$, and I Stantari phase 1 (MN). N/A: artefacts non-attributed to a specific obsidian source. 
4440-4000 BC), a period during which the large SC obsidian workshops became fully operational and increased the amount of obsidian of this type that circulated within the long-distance exchange networks (Lugliè, 2012).

These two hypotheses are not necessarily in contradiction with each other. The phase 3 of Renaghju is associated with the transition period between an early Middle Neolithic (cf. Bonu Ighinu) and a recent Middle Neolithic (cf. San Ciriaco). During this transition phase the megalithism appears in Corsica, which confirms that these displays are embedded in a period of strong chrono-cultural evolution. The rise of the megalithic phenomenon bears witness of the management of external relationships (D'Anna, 2011, 2015).

\section{Conclusions}

The present work confirms that obsidian provenance studies conducted on complete and well-dated assemblages can significantly improve our knowledge of the chrono-cultural evolution of ancient communities. This study led us to build new interpretations of the factors responsible for cultural changes. Yet, only collections stemming from single-phased and undisturbed stratigraphic contexts at sites whose functional status is already determined may lead to set our data in a general wide-range reconstruction. Chronocultural comparisons with assemblages from other sites are however unachievable at present, chiefly because of the lack of comparable data, with a small number of previous studies giving a representative view of obsidian consumption in a given reliably defined cultural and chronological frame. It is therefore evident that only the multiplication of sourcing campaigns on welldocumented and well-contextualised assemblages will allow the verification of our hypotheses.

To date, the internal comparison of the obsidians selection behaviour at the Cauria Plateau seems to be in general agreement with the shift in the Monte Arci production system which occurred in the transition to the late MN. In fact, the progressive and important increase of SC obsidians fits well within the contemporaneous early activity of the workshops dawned on the outcrops at the eastern flanks of the source, as reflected in the San Ciriaco late MN lithic assemblages in Sardinia. We still need to explore the significance of the extended exploitation of SB2 obsidians at MN Renaghju and I Stantari (different local supply strategies/needs, possible reuse of obsidians from previous EN phase?) as well as the rare occurrence of the SA type (chronological discrepancy in the massive exploitation/reduction of the relative Monte Arci outcrops?).

Likewise, a complementary diachronic and synchronic study, focusing on the coupling of the sourcing results with the typotechnological data obtained on obsidian assemblages from the Cauria plateau, will be necessary to reach a better understanding of the obsidian economies in place during the Neolithic.

\section{Acknowledgments}

Within Southern Cross GeoScience, we would like to thank Matthew Tonge for his management of the LA-ICP-MS and help during the analyses, as well as Mark Rosicky and Diane Fyfe for their precious help. At the CRP2A, we wish to thank Yannick Lefrais and Brigitte Spiteri for their technical assistance, as well as Pierre Guibert for his support. We also thank Tristan Carter for providing the geological obsidian samples from Antiparos. The fieldworks were funded by grants from the Collectivité Territoriale de Corse and the PCR 'Matières premières lithiques en Corse: territoires et interactions culturelles au Néolithique'. Marie Orange's PhD was funded by a Postgraduate scholarship from SCU and partly from the Australian Research Council Discovery grant [DP140100919]; her time at the CRP2A facility in France was financed by a PSE project (Université Bordeaux Montaigne), 'Études de provenance de l'obsidienne préhistorique: de l'importance d'une comparaison inter-laboratoire et inter-méthodes'. The authors would also like to thank the two anonymous reviewers for providing feedback, as well as Yaroslav Kuzmin and Clive Oppenheimer for the editing of the final version of this publication.

\section{Appendix A. Supplementary data}

Supplementary data related to this article can be found at https://doi.org/10.1016/j.quaint.2017.12.033.

\section{References}

Aitchison, J., 1982. The statistical analysis of compositional data. J. Roy. Stat. Soc. B 44, 139-177.

Aitchison, J., Barceló-Vidal, C., Pawlowsky-Glahn, V., 2002. Some comments on compositional data analysis in archaeometry, in particular the fallacies in Tangri and Wright's dismissal of logratio analysis. Archaeometry 44, 295-304.

Barca, D., De Francesco, A.M., Crisci, G.M., 2007. Application of Laser Ablation ICP-MS for characterization of obsidian fragments from peri-Tyrrhenian area. J. Cult. Herit. 8, 141-150.

Bressy, C., Bellot-Gurlet, L., D'Anna, A., Pelletier, D., Tramoni, P., 2003. Provenance et gestion des matières premières lithiques du site néolithique ancien cardial de Renaghju (Sartène, Corse-du-Sud). In: Surmely, F. (Ed.), Les matières premières lithiques en Préhistoire. Préhistoire du Sud-Ouest, Cressenac, France, pp. 71-79 supplément $\mathrm{N}^{\circ} 5$.

Bressy, C., Bellot-Gurlet, L., Convertini, F., D'Anna, A., Guendon, J.-L., Pelletier, D. Tramoni, P., 2007. Matières premières et circulation des matériaux dans le Néolithique ancien de Renaghju (Sartène, Corse-du-Sud). In: D'Anna, A., Cesari, J., Ogel, L., Vaquer, J. (Eds.), Corse et Sardaigne préhistoriques : relations et échanges dans le contexte méditerranéen. Comité des Travaux Historiques et Scientifiques, Paris, France, pp. 87-98.

Bressy, C.S., D'Anna, A., Poupeau, G., Le Bourdonnec, F.-X., Bellot-Gurlet, L. Leandri, F., Tramoni, P., Demouche, F., 2008. Chert and obsidian procurement of three Corsican sites during the $6^{\text {th }}$ and $5^{\text {th }}$ millenniums BC. Comptes Rendus Palevol 7, 237-248.

Bressy, C., Le Bourdonnec, F.X., Bellot-Gurlet, L., Colonna, A., D'Anna, A, Errera, M.G.L., Federzoni, N., Leandri, F., Lugliè, C., Poupeau, G., Tramoni, P., 2010 Matières premières lithiques en Corse néolithique : étude de cas. In: Delestre, X., Marchesi, H. (Eds.), Archéologie des rivages méditerraneens : 50 ans de Recherche. Errance, Paris, France, pp. 193-197.

Cann, J.R., Renfrew, C., 1964. The characterization of obsidian and its application to the Mediterranean region. Proc. Prehist. Soc. 30, 11-131.

Carter, T., Poupeau, G., Bressy, C., Pearce, N.J.G., 2006. A new programme of obsidian characterization at Çatalhöyük, Turkey. J. Archaeol. Sci. 33, 893-909.

Costa, L.J., 2006. Récents acquis sur la circulation préhistorique de l'obsidienne en Corse. Bull. Soc. Prehist. Fr. 103, 71-85.

Costa, L.-J., Cesari, J., 2003. Éléments de réflexion pour une approche des données sur l'exploitation de l'obsidienne en Corse. Sardinia. Corsica et Baleares Antiquae 1, 41-51.

Courtin, J., 1972. Le problème de l'obsidienne dans le Néolithique du Midi de la France. Revue des Études ligures, XXXIII ${ }^{\mathrm{e}}$ année. Hommage à Fernand Benoit 1 , 93-109.

D'Anna, A., 2011. Les statues-menhirs de Corse : chronologie et contextes, l'exemple de Cauria. In: Gruat, P., Garcia, D. (Eds.), Stèles et statues du début de l'âge du Fer dans le Midi de la France (VIII ${ }^{\mathrm{e}}-\mathrm{IV}^{\mathrm{e}}$ av. A. J.-C.) : chronologies, fonctions et comparaisons. Association pour la Diffusion de l'Archéologie Méridionale, Epona, Lattes, Paris, France, pp. 21-36.

D'Anna, A., 2014. Le plateau de Cauria (Sartène, Corse-du-Sud), quinze années de recherches archéologiques, un bilan d'étape. In: Sénépart, I., Léandri, F. Cauliez, J., Perrin, T., Thirault, E. (Eds.), Chronologie de la Préhistoire récente. Actualité de la recherche. Archives d'Écologie Préhistorique, Toulouse, France, pp. 309-322.

D'Anna, A., 2015. Les pierres dressées et les statues-menhirs de Corse : contexte, chronologie, origines. In: Rodriguez, G., Marchesi, H. (Eds.), Statues-menhirs et Pierres Levées du Néolithique à aujourd'hui. Service Régional de l'Archéologie Groupe archéologique Saint-Ponais, Montpellier, Saint-Pons-de-Thomières, France, pp. 313-327.

D'Anna, A., Marchesi, H., Tramoni, P., Gilabert, C., Demouche, F., 2001. Renaghju (Sartène, Corse-du-Sud), un habitat de plein-air néolithique ancien en Corse. Bull. Soc. Prehist. Fr. 98, 431-444.

D'Anna, A., Marchesi, H., Tramoni, P., 2002. Le site mégalithique de Renaghju à Sartène. In: Aspects du Mégalithisme de la Corse, Recherches en Cours et Perspectives, vol. 9. Préhistoire et Anthropologie Méditerranéenne, pp. 141-146 2000.

D'Anna, A., Marchesi, H., Pinet, L., Tramoni, P., Guendon, J.-L., 2003. Les alignements de menhirs de Renaghju dans leur contexte du plateau de Cauria (Sartène Corse-du-Sud). In: Temps et Espaces Culturels du $6^{\mathrm{e}}$ au $2^{\mathrm{e}}$ millenaire en France 
du Sud, vol. 15. Mémoires d'Archéologie Méridionale, Nîmes, France, pp. $357-368$.

D'Anna, A., Guendon, J.-L., Pinet, L., Tramoni, P., 2006. Espaces, Territoires et Mégalithes : le plateau de Cauria (Sartène, Corse-du-Sud) au Néolithique et à l'âge du Bronze. In: Duhamel, P. (Ed.), Impacts interculturels au Neolithique moyen. Du terroir au territoire : societes et espaces. Revue archéologique de l'Est, Dijon, France, pp. 191-213. Supplément 25.

D'Anna, A., Guendon, J.-L., Orsini, J.-B., Pinet, L., Tramoni, P., 2007a. Les alignements mégalithiques du plateau de Cauria (Sartène, Corse-du-Sud). In: D'Anna, A Cesari, J., Ogel, L., Vaquer, J. (Eds.), Corse et Sardaigne préhistoriques : relations et échanges dans le contexte méditerranéen. Comité des Travaux Historiques et Scientifiques, Paris, France, pp. 211-223.

D'Anna, A., Guendon, J.-L., Orsini, J.-B., Pinet, L., Tramoni, P., 2007b. Le plateau de Cauria du Néolithique à l'âge du Bronze, de la lecture événementielle à l'approche pluridisciplinaire anthropologique, hommage à Roger Grosjean. In: Evin, J. (Ed.), Un siècle de construction du discours scientifique en Préhistoire. Société Préhistorique Française, Paris, France, pp. 331-346.

Eerkens, J.W., Spurling, A.M., Gras, M.A., 2008. Measuring prehistoric mobility strategies based on obsidian geochemical and technological signatures in the Owens Valley, California. J. Archaeol. Sci. 35, 668-680.

Freund, K.P., 2014. Obsidian Consumption in Chalcolithic Sardinia: a view from Bingia 'e Monti. J. Archaeol. Sci. 41, 242-250.

Freund, K.P., Tykot, R.H., 2011. Lithic technology and obsidian exchange networks in Bronze Age Nuragic Sardinia (Italy). Archaeol. Anthropol. Sci. 3, 151-164.

Gratuze, B., 1999. Obsidian characterization by laser ablation ICP-MS and its application to prehistoric trade in the Mediterranean and the Near East: sources and distribution of obsidian within the Aegean and Anatolia. J. Archaeol. Sci. 26 , 869-881.

Kellett, L.C., Golitko, M., Bauer, B.S., 2013. A provenance study of archaeological obsidian from the Andahuaylas region of southern Peru. J. Archaeol. Sci. 40, 1890-1902.

Lanfranchi, (de), F., 1976. Destruction d'un site cardial à Bonifacio (Corse). Bull. Soc. Prehist. Fr. 73, 273-275.

Lanfranchi, (de), F., 1980. L'obsidienne préhistorique corso-sarde : les échanges et les axes de circulation. Bull. Soc. Prehist. Fr. 77, 115-122.

Lanfranchi, (de), F., 1987. Le Néolithique de Curacchiaghiu. Position chronologique et culture matérielle. Son importance dans l'ensemble corso-sarde. In: Guilaine, J., Courtin, J., Roudil, J.-L., Vernet, J.-L. (Eds.), Premières communautés paysannes en Méditerranée occidentale. Éditions du CNRS, Paris, France, pp. 433-442.

Le Bourdonnec, F.-X., 2007. Aspects Archéométriques de la Circulation de l'Obsidienne Préhistorique. Développements Analytiques et Applications en Corse, Sardaigne et Éthiopie. PhD Dissertation. Université Michel de Montaigne Bordeaux, 3, Pessac, France.

Le Bourdonnec, F.-X., Bontempi, J.-M., Marini, N., Mazet, S., Neuville, P.F. Poupeau, G., Sicurani, J., 2010. SEM-EDS characterization of western Mediterranean obsidians and the Neolithic site of A Fuata (Corsica). J. Archaeol. Sci. 37, 92-106.

Le Bourdonnec, F.-X., Poupeau, G., Lugliè, C., D'Anna, A., Bellot-Gurlet, L., BressyLeandri, C.S., Pasquet, A., Tramoni, P., 2011. New data and provenance of obsidian blocks from Middle Neolithic contexts on Corsica (western Mediterranean). Comptes Rendus Palevol 10, 259-269.

Le Bourdonnec, F.-X., Nomade, S., Poupeau, G., Guillou, H., Tushabramishvili, N., Moncel, M.-H., Pleurdeau, D., Agapishvili, T., Voinchet, P., Mgeladze, A., Lordkipanidze, D., 2012. Multiple origins of Bondi Cave and Ortvale Klde (NW Georgia) obsidians and human mobility in Transcaucasia during the Middle and upper Palaeolithic. J. Archaeol. Sci. 39, 1317-1330.

Le Bourdonnec, F.-X. D'Anna, A., Poupeau, G., Lugliè, C., Bellot-Gurlet, L., Tramoni, P., Marchesi, H., 2015. Obsidians artefacts from Renaghju (Corsica Island) and the Early Neolithic circulation of obsidian in the Western Mediterranean. Archaeol. Anthropol. Sci. 7, 441-462.

Leandri, F., Demouche, F., Costa, L.-J., Tramoni, P., Gilabert, C., Béraud, A., Jorda, C., 2007. Le site du Monte-Revincu (Santo-Pietro-di-Tenda, Haute-Corse) : Contribution à la connaissance du Néolithique moyen de la Corse. In D'Anna, A., Cesari, J., Ogel, L., Vaquer, J. (Eds.), Corse et Sardaigne préhistoriques : relations et Échanges dans le contexte méditerranéen. Comité des Travaux Historiques et Scientifiques, Paris, France, pp. 165-183.

Lugliè, C., 2012. From the perspective of the source. Neolithic production and exchange of Monte Arci obsidians (Central-western Sardinia). In: Borrell, M.,
Borrell, F., Bosch, J., Clop, X., Molist, M. (Eds.), Congrés Internacional Xarxes al Neolític - Neolithic Networks, vol. 5. Rubricatum, Revista del Museu de Gavà, Gavà, Spain, pp. 173-180.

Lugliè, C., Le Bourdonnec, F.-X., Poupeau, G., Atzeni, E., Dubernet, S., Moretto, P., Serani, L., 2007. Early Neolithic obsidians in Sardinia (Western Mediterranean): the Su Carroppu case. J. Archaeol. Sci. 34, 428-439.

Lugliè, C., Le Bourdonnec, F.-X., Poupeau, G., Congia, C., Moretto, P., Calligaro, T., Sanna, I., Dubernet, S., 2008. Obsidians in the Rio Saboccu (Sardinia, Italy) campsite: provenance, reduction and relations with the wider Early Neolithic Tyrrhenian area. Comptes Rendus Palevol 7, 249-258.

Lugliè, C., Congia, C., Le Bourdonnec, F.-X., Poupeau, G., Dubernet, S., Calligaro, T., Sanna, I., 2009. Obsidian economy in the Rio Saboccu open-air early Neolithic site (Sardinia, Italy). In: Sternke, F., Eigeland, L. Costa, L.-J. (Eds.), Non-flint Raw Material use in Prehistory: Old Prejudices and New Directions. Archaeopress, Oxford, England, pp. 203-215. BAR International Series 1939.

Mérimée, P., 1840. Notes d'un voyage en Corse. Fournier Jeune, Paris, France, p. 256.

Orange, M., Carter, T., Le Bourdonnec, F.-X., 2013. Sourcing obsidian from Tell Aswad and Qdeir 1 (Syria) by SEM-EDS and EDXRF: Methodological implications. Comptes Rendus Palevol 12, 173-180.

Orange, M., Le Bourdonnec, F.-X., Scheffers, A., Joannes-Boyau, R., 2016. Sourcing obsidian: a new optimized LA-ICP-MS protocol. Star: Sci. Technol. Archaeol. Res. 2, 192-202.

Orange, M., Le Bourdonnec, F.-X., Bellot-Gurlet, L., Lugliè, C., Dubernet, S., BressyLeandri, C., Scheffers, A., Joannes-Boyau, R., 2017. On sourcing obsidian assemblages from the Mediterranean area: analytical strategies for their exhaustive geochemical characterisation. J. Archaeol. Sci. Rep. 12, 834-844.

Perlès, C., 2012. Quand 'diffusion' ne veut pas dire 'interaction'. In: Borrell, M., Borrell, F., Bosch, J., Clop, X., Molist, M. (Eds.), Congrés Internacional Xarxes al Neolític - Neolithic Networks, vol. 5. Rubricatum, Revista del Museu de Gavà, Gavà, Spain, pp. 585-590.

Poupeau, G., Lugliè, C., D’Anna, A., Le Bourdonnec, F.-X., Bellot-Gurlet, L., Carter, T. Bressy-Leandri, C.S., 2010a. Circulation et origine de l'obsidienne préhistorique en Méditerranée : un bilan de cinquante années de recherches. In: Delestre, X., Marchesi, H. (Eds.), Archéologie des rivages méditerraneens : 50 ans de recherche. Errance, Paris, France, pp. 183-191.

Poupeau, G., Le Bourdonnec, F.-X., Carter, T., Delerue, S., Shackley, S.M., Barrat, J.-A., Dubernet, S., Moretto, P., Calligaro, T., Milić, M., Kobayashi, K., 2010b. The use of SEM-EDS, PIXE and EDXRF for obsidian provenance studies in the Near East: a case study from Neolithic Çatalhöyük (central Anatolia). J. Archaeol. Sci. 37, 2705-2720.

Poupeau, G., Le Bourdonnec, F.-X., Bellot-Gurlet, L., 2014. Caractérisation et circulation de l'obsidienne. In: Dillmann, P., Bellot-Gurlet, L. (Eds.), Circulation et provenance des matériaux dans les sociétés anciennes. Éditions des Archives Contemporaines, Collection "Sciences Archéologiques", Paris, France, pp. 9-33. SAS, 2012. JMP. SAS Institute Inc., Cary, NC, Version 10.

Sicurani, J., 2008. Étude technologique et typologique du matériel lithique taillé trouvé en place dans quelques sites majeurs du nord-ouest (Balagne) de la Corse. PhD Dissertation. Université de Corse, Corté, France.

Terradas, X., Gratuze, B., Bosch, J., Enrich, R., Esteve, X., Oms, F.X., Ribé, G., 2014. Neolithic diffusion of obsidian in the western Mediterranean: new data from Iberia. J. Archaeol. Sci. 41, 69-78.

Tykot, R.H., 1996. Obsidian procurement and distribution in the Central and Western Mediterranean. J. Mediterr. Archaeol. 9, 39-82.

Tykot, R.H., 2002. New approaches to the characterization of obsidian from the Mediterranean island sources: interpreting chronological change in Neolithic Sardinia and Corsica. In: Vandiver, P.B., Goodway, M., Druzik, J.R., Mass, J.L. (Eds.), Materials Issues in Art and Archaeology VI, Materials Research Society Proceedings, vol. 712. Cambridge University Press, Warrendale, Pennsylvania, U.S.A., pp. $143-157$

Tykot, R.H., Lai, L., Tozzi, C., 2011. Intra-site obsidian subsource patterns at Contraguda, Sardinia (Italy). In: Turbanti-Memmi, I. (Ed.), Proceedings of the 37th International Symposium on Archaeometry. Springer, Siena, Italy, pp. 321-328.

Vaquer, J., 2007. Le rôle de la zone nord-tyrrhénienne dans la diffusion de l'obsidienne en Méditerranée nord-occidentale au Néolithique. In: D'Anna, A., Cesari, J., Ogel, L., Vaquer, J. (Eds.), Corse et Sardaigne préhistoriques : relations et échanges dans le contexte méditerranéen. Comité des Travaux Historiques et Scientifiques, Paris, France, pp. 99-119.

Williams-Thorpe, O., 1995. Obsidian in the Mediterranean and the Near East: a provenancing success story. Archaeometry 37, 217-248. 